УДК 78:7.079

DOI https://doi.org/10.31723/2524-0447-2021-32-1-20

\author{
Вадим Іванович Колосок \\ ORCID: 0000-0003-2249-5799
}

аспірант кафедри академічного і естрадного вокалу та звукорежисури Національної академії керівних кадрів культури і мистецтв, режкисер радіопрограм Українського радіо kolosok@ukr.net

\title{
СКЛАДНИКИ КОМУНІКАЦІЙНИХ ПРОЦЕСІВ У СУЧАСНОМУ АКАДЕМІЧНОМУ ТА МАСОВОМУ МУЗИЧНОМУ МИСТЕЦТВІ УКРАЇНИ: ІСТОРИЧНІ ПЕРЕДУМОВИ, СТРУКТУРА, НАПРЯМИ ДОСЛІДЖЕНЬ
}

Метою роботи є виявлення ключових принципів взаємозв'язків окремих ланок музичної комунікації, об'єднання фізичних та віртуальних складових частин цього процесу в загальну структуру комунікаційних контактів у сучасному академічному і масовому музичному мистецтві. Методологія дослідження грунтується на системно-аналітичному методі (феномен музичної комунікації розглядається як система комунікативних ланок, елементи якої перебувають у єдності і формують своєю взаємодією цілісність); порівняльно-історичному (зіставлення особливостей музично-комунікативних процесів у XVII-XIX, XX та XXI століттях); методах аналізу даних та інтерпретації показників. Наукова новизна роботи полягає у доповненні загальноприйнятої схеми взаємозв'язків суб'єктів музичної комунікації новими ланками, що відповідають найновішим дискурсам комунікативних контактів у сучасному академічному мистецтві та масовій культурі. Висновки. Феномен музичної комунікації є складною системою комунікативних ланок, елементи якої перебувають у структурній єдності і своєю взаємодією формують загальну цілісність. Нами запропоновано таку базову структуру комунікації у сучасному академічному та масовому музичному мистецтві: композитор - твір - виконавець - медіаформа твору - комунікативний простір - слухач. Додатковими комунікаційними ланками иієї структури вважаємо видавия, редактора, музикознавия, критика (блогера), педагога-консультанта, автора обробки, диригента (керівника виконавського колективу), звукорежисера аудіозапису, відеорежисера, продюсера, саундпродюсера, саунддизайнера, артдиректора, звукорежисера концерту та режисера трансляції. У роботі наведено схему структури музичної комунікації, де стрілками вказано напрямок комунікативного процесу (однобічні стрілки) чи комунікаційної взаємодії елементів системи (двобічні стрілки). Також створено таблицю

(c) Колосок В. І., 2021 
«Роль основних ланок музичної комунікації,, де проаналізовано кілька найважливіших, на наш погляд, елементів музично-комунікативного процесу в сучасній академічній і масовій музичній культурі України.

Ключові слова: музична комунікація, комунікаційні ланки, композитор, твір, виконавець, медіаформа твору, комунікативний простір, слухач, академічне музичне мистецтво, масове музичне мистецтво.

Kolosok Vadym Ivanovych, Postgraduate Student at the Department of Academic and Pop Vocal and Sound Directing of National Academy of Culture and Arts Management, Director of Radio Programs of Ukrainian Radio

Components of communication processes in modern academic and massive musical art of Ukraine: historical prerequisites, structure, directions of research

Research objective is to identify the key principles of interconnection of individual parts of musical communication, combining the physical and virtual components of this process into a general structure of communication contacts in modern academic and massive music art. The research methodology is based on the system-analytical method (the phenomenon of musical communication is considered as a system of communicative links, the elements of which are in unity and form an integrity through their interaction); comparative-historical (comparison of features of musicalcommunicative processes in the XVII-XIX,XX and XXI centuries); methods of data analysis and interpretation of indicators. The scientific novelty of the work lies in supplementing the generally accepted scheme of relationships of the subjects of musical communication with new links that correspond to the latest discourses of communicative contacts in modern academic art and mass culture. Conclusions. The phenomenon of musical communication is a complex system of communicative links, the elements of which are in structural unity and their interaction forms a common integrity. We have proposed the following basic structure of communication in contemporary academic and massive art: composer - work - performer - media form of the work - communicative space - listener. Additional communication links of this structure include: publisher, editor, musicologist, critic (blogger), teacher-consultant, author of the arrangement, conductor, sound engineer, video director, producer, sound producer, sound designer, art director, director broadcasts. The diagram of the structure of musical communication is given in the work, where the arrows indicate the direction of the communicative process (one-sided arrows) or the communication interaction of the system elements (two-sided arrows). The table "The role of the main links of musical communication" created, which analyzes some of the most important, in our opinion, elements of the musical-communicative process in modern academic and massive music culture of Ukraine.

Key words: musical communication, communication links, composer, work, performer, media form of the work, communicative space, listener, academic musical art, mass musical art. 
Актуальність теми дослідження. Швидкий розвиток інформаційних технологій упродовж останніх десятиліть дає нові імпульси змінам в усіх галузях суспільного і культурного життя, зокрема в музичному мистецтві. Ми стали свідками появи в Україні абсолютно нових музичних професій, таких як саундпродюсер, саунддизайнер, діджей, віджей тощо. У більшості мешканців нашої держави завдяки використанню сучасних гаджетів та мережі Інтернет з'явилася можливість доступу в будь-який час до величезної кількості творів світового і вітчизняного музичного мистецтва у вигляді медіафайлів на інтернет-ресурсах та у соціальних мережах. Нині трансляції виступів українських і закордонних виконавців, концерти, вистави, музичні ток-шоу можна дивитися online або у запису необмежену кількість разів.

Такі зміни наочно демонструють стрімке зростання значення музично-комунікативних процесів як в особистому житті кожної людини, так й у вимірі усієї музичної культури загалом.

Епоха цифрових інформаційно-комунікаційних технологій додає усе нових складників до усталеного впродовж століть процесу музичної комунікації. Для багатьох людей, глибоко занурених в особливості сучасної масової культури, не викликають найменшого здивування такі твердження: «піти на концерт діджея», «ознайомитись із діджей-сетом», «звернутись до саунддизайнера», «отримати відгук від музичного блогера» тощо. I хоча усі ці комунікативні акти безпосередньо стосуються саме музичного мистецтва, музикознавча наука поки що не знайшла їм відповідного місця серед музично-комунікативних процесів. Так, актуальним $є$ питання подальшого дослідження цих та інших феноменів маскультури, визначення їх зв'язків з академічною музичною традицією та створення розширеної моделі взаємодії різних ланок комунікації в процесі музичної діяльності.

Метою дослідження є виявлення ключових принципів взаємозв'язків окремих ланок музичної комунікації, об'єднання фізичних та віртуальних складових частин цього процесу в загальну структуру комунікаційних контактів у сучасному академічному і масовому музичному мистецтві.

Наукова новизна роботи полягає у доповненні загальноприйнятої схеми взаємозв'язків суб'єктів музичної комунікації новими ланками, що відповідають найновішим дискурсам 
комунікативних контактів у сучасному академічному мистецтві та масовій культурі,

Виклад основного матеріалу. Різні аспекти комунікативних особливостей музичного мистецтва аналізують у наукових працях чимало українських та зарубіжних дослідників. Музикознавець (і музичний редактор колишньої фірми грамзапису «Мелодія») Ірина Орлова докладно розглядає музично-історичні передумови та закономірності виникнення такого технічного і художнього явища, як звукозапис [5]. Українська музикознавиця Олена Берегова досліджує новітні тенденції у сфері взаємодії академічного й масового музичного мистецтва 3 інформаційно-комунікативними технологіями [1]. Культуролог Марк Найдорф вивчає музичну комунікацію, що склалася на основі масових інформаційних каналів (радіо, телебачення, CD, DVD, Інтернет) [4]. Музикознавці Олександр Злотник та Валерія Шульгіна розбирають різноманіття комунікативних зв'язків та реалізацій мистецьких інтерпретацій музичного тексту в процесі виконання твору і сприйняття його реципієнтом [2]. Соціолог Ірина Сєргєєва займається вивченням соціокультурних джерел виникнення i розвитку масових музичних жанрів та поясненням їх комунікативних особливостей [6]. Культуролог Ірина Корсакова досліджує цілісний феномен музичної комунікації, адже в результаті зміни механізмів взаємодії в сучасних інформаційних умовах виникли нові музичні професії і, відповідно, нові суб'єкти музичної комунікації [3].

Очевидно, що першопочатковому етапу зародження музичної культури був притаманний так званий «первинний синкретизм», тобто нерозчленованість учасників процесу на виконавців і слухачів. Власне, ця ситуація зберіглася й дотепер у фольклорному мистецтві, де учасники, скажімо, народно-обрядового дійства виступають і дійовими особами, і заглибленими у процес глядачами, а часто й співавторами виконуваних музичних творів.

Фольклорне музикування припускає багатоваріантність (кожен виконавець має право заспівати одну й ту ж пісню по-своєму). Так само рівноправними $є$ всі варіанти у тих музичних культурах, які орієнтуються на принцип виконавської імпровізації (як-от джаз чи азербайджанський мугам). Але в цих культурах обов'язково присутній розподіл на музиканта (майстра імпровізації) і слухача. На можливість саме 
такої двокомпонентної «комунікативної формули» у сучасному мистецтві звертають увагу музикознавці Олександр Злотник та Валерія Шульгіна у статті «Комунікативні функції художнього спілкування в музичному мистецтві»: «Головні учасники музичного комунікативного процесу: адресант або комунікатор - відправник повідомлення (автор, інтерпретатори-виконавці), й адресат або реципієнт (перцепієнт) одержувач повідомлення (слухачі, глядачі), на сприйняття i оцінку яких розрахований художній твір [2, с. 33].

Европейська музична традиція, як відомо, розвивалася шляхом письмової фіксації музичних творів за допомогою спеціальних знаків - крюків, невм, а згодом нот. Завдяки добре розвинутій системі нотації будь-який музикант міг виконати чужий твір дуже близько до оригіналу. Це уможливлювало збільшення репертуару публічних концертів і зацікавлювало авторів до якнайточнішої фіксації своїх творінь.

Орієнтовно з ХІ століття діяльність європейських музичних майстрів починає поділятися на два види: створення й виконання власної музики та інтерпретацію чужих творів. Таким чином, відтоді й аж приблизно до середини XIX століття панівною комунікативною системою європейського професійного музичного мистецтва була «класична» тріада «композитор - виконавець - слухач». Радянська музикознавиця Ірина Орлова вважає основною «рушійною силою» стрімкого поширення європейським, а згодом й іншими теренами такого розподілу ланок комунікаційних процесів саме появу нот (спочатку рукописних, а згодом друкованих), котрі, «виконуючи функцію історичної пам'яті, стимулювали карколомну еволюцію музичного мистецтва» [5, с. 24]. Отож, на думку цієї дослідниці, «спосіб фіксації музичного матеріалу (або його відсутність) - один із визначальних факторів у формуванні музичної комунікативної системи певного типу» [5, с. 25].

Подальша еволюція музичної нотації, що за кілька століть досягла своєї межі, призвела до виокремлення приблизно iз середини XIX століття, на думку I. Орлової, четвертого учасника тієї «комунікативної тріади», адже музичне мислення симфонізувалося, кількісний склад оркестрів повсякчас збільшувався, тому виникла необхідність у окремому майстрі інтерпретації - диригенті (тобто в художньому керівникові оркестру чи хору). «Поява в музичній культурі 
фігури диригента - перший етап у формуванні виконавського блоку розповсюдження, який посяде панівне місце в системі музичної комунікації XX століття», - зазначала дослідниця [5, с. 28].

У своїй статті I. Орлова фактично наближається до визнання того, що не лише «живі» учасники процесу створення, інтерпретування та сприйняття музики (композитор, виконавець, диригент, слухач), а й віртуальні суб'єкти музичної комунікації, як-от нотний текст твору чи його аудіозапис, є такими ж рівноправними ланками системи музичної комунікації.

Отож, упродовж останніх десятиліть концепція трьох основних учасників музично-комунікативного процесу (композитора, виконавця й слухача, що відповідала базовим видам музичної діяльності - створенню музики, іiі виконанню та сприйняттю) почала поступово розширюватися у працях науковців. Сучасні дослідники, як правило, вважають за доцільне збільшення кола суб’єктів, що задіяні в процесі такої комунікаціiі, але при цьому виокремлюють серед них основні сегменти, без наявності котрих уважають цей процес неможливим. Так, соціолог Ірина Сєргєєва в дисертаційній роботі «Особливості комунікаційних процесів масової музичної культури» одним із ключових елементів системи маскультури, який «починає і одночасно завершує «комунікаційний ланцюжок», уважає продюсера. У дослідниці цей «комунікаційний ланцюжок» складається з 5 компонентів: продюсер, автор, виконавець, слухач (глядач), критик. Далі I. Сєргєєва зауважує, що у цю схему варто включити інші складники, що виконують роль сполучника між елементами комунікації, і першість серед них належить засобам масової інформації [6, с. 8].

Культуролог Ірина Корсакова у дисертації «Музична комунікація: генезис та історико-культурні трансформації» пов'язує систему суб'єктів музичної комунікації зі структурою комунікативного акту: композитор (створення музичного дискурсу), виконавець (його актуалізація та інтерпретація), слухач (сприйняття дискурсу), критик (його оцінка) та продюсер (проектування музичного дискурсу) [3, с. 22]. В іншому місці своєї роботи вона перераховує ще декілька важливих, на iiі погляд, суб'єктів музичної комунікації: режисер, менеджер, аранжувальник, педагог і учень, майстер і новачок, професіонал і любитель [3, с. 6]. 
Музикознавці Олександр Злотник та Валерія Шульгіна виокремлюють таких суб'єктів музичного діалогу: композитора, виконавця, слухача (реципієнта), педагога, учня, дослідника, критика тощо [2, с. 33].

Якщо вищезгадані дослідники використовували шлях кількісного збільшення основних суб'єктів музично-комунікативного процесу, то альтернативною, на наш погляд, є концепція розширення просторових характеристик цього процесу за рахунок додавання до нього таких нематеріальних об'єктів комунікації, як сам твір та канал його трансляції. Зокрема, музикознавиця Олена Берегова у статті «Академічне музичне мистецтво та сучасні інформаційно-комунікаційні технології: дискурс взаємодії» пропонує таку структуру художньо-комунікативного акту: композитор - твір - виконавець твору канал трансляції - слухач. Додатковими ланками між митцем і слухачем, на погляд науковиці, є видавець, продюсер, редактор, критик тощо [1, с. 26, 27].

У вищезазначеній роботі О. Берегова докладно пояснює, що таке, на її думку, «канал трансляції»: «Уже понад 100 років трансляція художніх цінностей у галузі музичного мистецтва відбувається у двох «форматах»:

1) традиційного концертного виконавства (музична комунікація проходить безпосередньо в концертному залі);

2) у віртуальному звуковому та візуальному просторі через: електронні засоби масової комунікації (радіоефіри, телетрансляції (як прямі, з місця події, так і в запису)); електронні аудіо- та відеоносії (CD, DVD тощо); мережу Інтернет (персональні та корпоративні вебсайти, соціальні мережі)» [1, c. 25].

На наш погляд, запропонована О. Береговою концепція взаємодії між різними ланками музично-комунікативних процесів є подальшим розвитком позицій, озвучених три $з$ половиною десятиліття тому музикознавцем I. Орловою. Єдиним, із чим варто не погодитися, є універсальність використаного Оленою Береговою терміна «канал трансляції». Можливо, цей науковий вислів відповідав покладеним на нього функціям наприкінці 20 століття, коли поруч із концертним виконавством електронними засобами передання інформації були лише радіо, телебачення і CD-диски. Нині ж, із розвитком комп'ютерної мережі Інтернет, «глобальна павутина» стала одночасно засобом пошуку, вибору 
треку, кліпу чи трансляційного запису і водночас - каналом як «прямого», так і зворотного зв'язку між слухачем (глядачем) та іншими ланками музичного процесу (композитор, виконавець, продюсер, критик), зокрема через соціальні мережі. Тому ми пропонуємо використовувати термін, який трапляється у проаналізованих роботах кількох науковців, зокрема I. Корсакової, - «комунікативний простір». Це визначення, на наш погляд, вдало підходить для окреслення і концертного залу, де відбувається спілкування слухачів із музичним мистецтвом, і телерадіопростору, і віртуальної інтернет-мережі.

Так, ми вважаємо базовою таку структуру музичної комунікації у сучасному мистецтві: композитор - твір - виконавець - медіаформа твору - комунікативний простір слухач. У запропонованій далі схемі структури музичної комунікації ці елементи виокремлено за допомогою геометричних рамок.

Аналізуючи ланку «композитор», варто зазначити, що особливістю сучасної масової культури є те, що люди, які генерують культурний продукт, часто залишаються маловідомими для слухачів. На анонімність автора і центральну роль виконавця у масовому музичному мистецтві вказує, зокрема, культуролог Марк Найдорф, зазначаючи: «Можна стверджувати, що у більшості випадків предметом масової комунікації $є$ не сам по собі музичний текст, а образ артиста, що подається в процесі його виконання» [4, с. 70].

Під поняттям «твір» ми, як й інші дослідники, зокрема О. Берегова, розуміємо композиторський задум, нотний текст, партитуру, тобто той вигляд твору, який обов'язково потребує подальшого його відтворення виконавцем. Що стосується медіаформи твору, то якраз однією з особливостей сучасного масового мистецтва, на думку М. Найдорфа, є те, що слухачеві пропонується готовий (записаний) твір, який надалі відтворюється суто технічно, абсолютно не залежно від волі й зусиль виконавців [4, с. 72]. У більшості випадків нині у комунікативному процесі використовується готовий відеокліп чи аудіофайл. Під час виконання академічної музики у концертному залі ця ланка може бути відсутньою, але під час концертів масового музичного мистецтва майже завжди використовується фонограма, зокрема інструментального супроводу. 
До шести базових, на наш погляд, елементів комунікаційного процесу ми додали й інших суб'єктів музичної комунікації, деякі з цих ланок комунікаційного процесу були окреслені в проаналізованих наукових працях. Зокрема, між «композитором» і «твором» пропонується розмістити професії видавця і редактора, які своєю діяльністю допомагають поширенню нотної версії авторського творіння; між «твором» $\mathrm{i}$ «виконавцем» ми розташували тих, хто допомагає процесу якісної інтерпретації композиторського і виконавського задуму: музикознавця, критика (блогера), педагога-консультанта, автора обробки, диригента (керівника виконавського колективу). Між «виконавцем» і «медіаформою твору» перебувають, на нашу думку, звукорежисер аудіозапису та відеорежисер; між «виконавцем» і «комунікативним простором» - продюсер, саундпродюсер, саунддизайнер; між «виконавцем» і «слухачем» ми розташували артдиректора, між «комунікативним простором» і «слухачем» виокремили звукорежисера концерту та режисера трансляції. Ті види музичної діяльності, які не потрапили до цього списку, як правило, близькі до одного з використаних нами понять (наприклад концертмейстер або діджей - це різновиди виконавця музики).

Стрілки на схемі вказують напрямок музично-комунікаційних процесів: композитор створює твір, а педагог-консультант допомагає виконавцеві його вивчити тощо. Двобічні стрілки означають взаємодію в обох напрямках, адже висловлені критиком зауваження постійно допомагають виконавцеві змінювати своє прочитання музичного твору; медіаформа твору за допомогою комунікативного простору може випадково чи цілеспрямовано потрапити до слухача, але останній і сам має змогу звернутися до такого простору (як-от мережі Інтернет) у пошуках улюбленої композиції тощо.

Пропонуємо також таблицю «Роль основних ланок музичної комунікації», де проаналізовано кілька важливих, на наш погляд, елементів музично-комунікативного процесу в сучасній академічній та масовій музичній культурі. Під час складання таблиці нами частково використано матеріали зі статті «Академічне музичне мистецтво та сучасні інформаційнокомунікаційні технології: дискурс взаємодії» музикознавиці Олени Берегової [1, с. 32]. 
Схема структурн музнчної комунікації

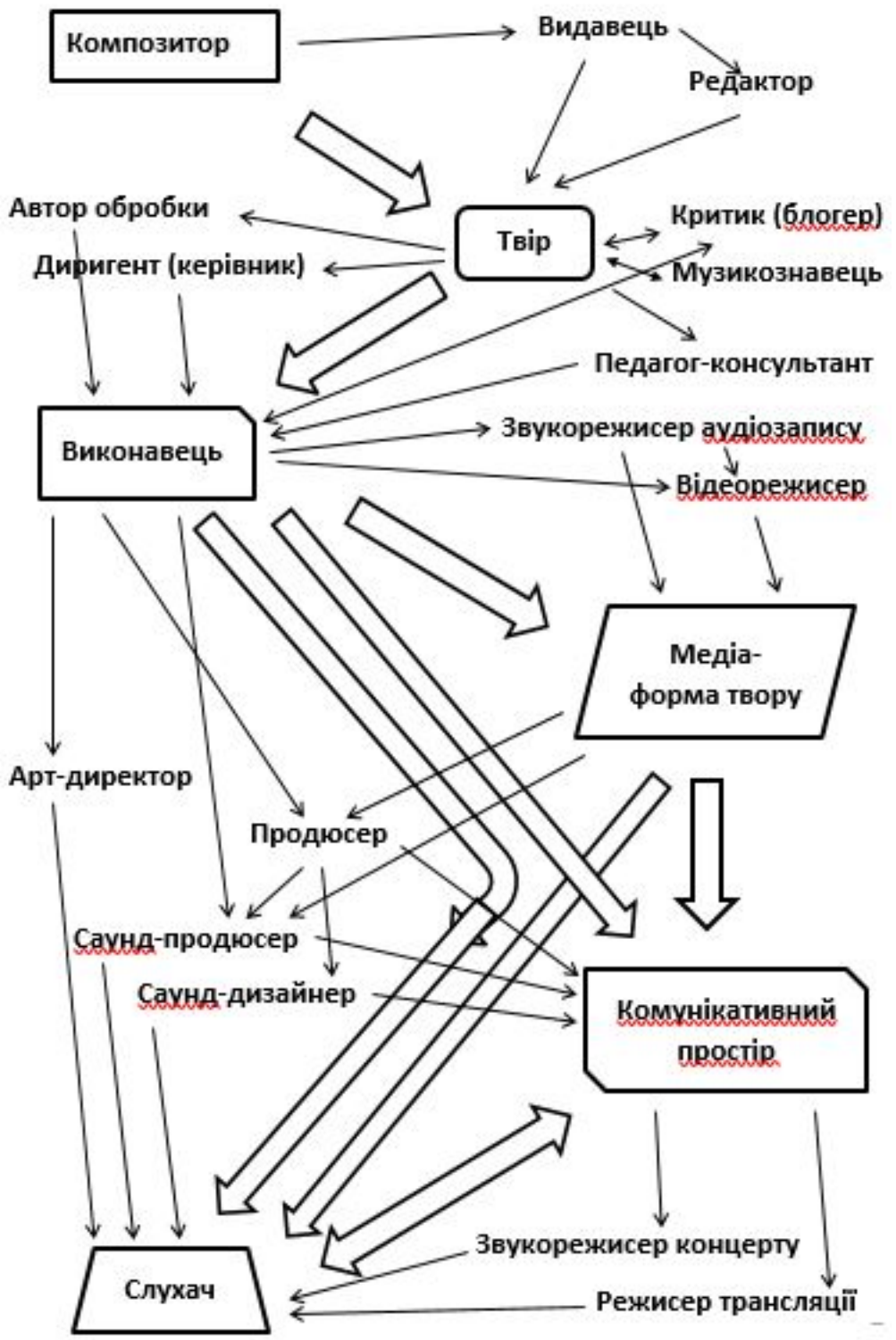


Таблиця 1

Роль основних ланок музичної комунікації

\begin{tabular}{|c|c|c|}
\hline $\begin{array}{c}\text { Ланки музичної } \\
\text { комунікації } \\
\end{array}$ & $\begin{array}{c}\text { Академічна музична } \\
\text { культура } \\
\end{array}$ & $\begin{array}{c}\text { Масова музична } \\
\text { культура } \\
\end{array}$ \\
\hline 1 & 2 & 3 \\
\hline КОМПОЗИТОР & $\begin{array}{l}\text { Непересічна особи- } \\
\text { стість, музикант висо- } \\
\text { кого рівня. Вчиться у } \\
\text { професійних навчаль- } \\
\text { них закладах тривалий } \\
\text { період часу. }\end{array}$ & $\begin{array}{l}\text { Не завжди є профе- } \\
\text { сійним музикантом. } \\
\text { Часто залишається для } \\
\text { слухача анонімним } \\
\text { або маловідомим, як } \\
\text { правило, перебуває «в } \\
\text { тіні» образу виконавця. }\end{array}$ \\
\hline TBIP & $\begin{array}{l}\text { Оригінальний як за } \\
\text { змістом, так і за набо- } \\
\text { ром засобів музичної } \\
\text { виразності. Баналь- } \\
\text { ність може використо- } \\
\text { вуватися як один із } \\
\text { таких засобів. Має } \\
\text { некомерційний харак- } \\
\text { тер. Візуальна склад- } \\
\text { ник відіграє все більшу } \\
\text { роль. Це принципово } \\
\text { унікальний, «штучний» } \\
\text { товар. }\end{array}$ & $\begin{array}{l}\text { Не завжди оригіналь- } \\
\text { ний, але яскравий за } \\
\text { змістом чи засобами } \\
\text { виразності. Візуаль- } \\
\text { ний складник відіграє } \\
\text { дуже велику роль. Має } \\
\text { принципово багатоти- } \\
\text { ражний характер, орі- } \\
\text { єнтований на шоу та } \\
\text { комерційний успіх. У } \\
\text { свідомості слухачів, як } \\
\text { правило, пов'язується } \\
\text { не з композитором, а } з \\
\text { виконавцем. }\end{array}$ \\
\hline ВИКОНАВЕЦЬ & $\begin{array}{l}\text { Співавтор твору, } \\
\text { допомагає розкрити } \\
\text { його глибинний зміст. } \\
\text { Вчиться у професійних } \\
\text { навчальних закладах } \\
\text { тривалий період часу. }\end{array}$ & $\begin{array}{l}\text { Може не мати музич- } \\
\text { ної освіти. Яскрава } \\
\text { особистість, чий образ } \\
\text { іноді створюється } \\
\text { зусиллями продюсе- } \\
\text { рів та іміджмейкерів. } \\
\text { Часто основну музичну } \\
\text { роботу з надання твору } \\
\text { особливих рис виконує } \\
\text { саундпродюсер, а голос } \\
\text { виконавця може бути } \\
\text { лише «живим інстру- } \\
\text { ментом» для цього. }\end{array}$ \\
\hline
\end{tabular}


Продовження таблиці 1

\begin{tabular}{|c|c|c|}
\hline 1 & 2 & 3 \\
\hline $\begin{array}{l}\text { САУНДПРО- } \\
\text { ДЮСЕР }\end{array}$ & $\begin{array}{l}\text { Використовується дуже } \\
\text { рідко, наприклад, у } \\
\text { оркестрових колекти- } \\
\text { вах, яким доводиться } \\
\text { регулярно робити сту- } \\
\text { дійні аудіозаписи (при- } \\
\text { клад - Лондонський } \\
\text { симфонічний оркестр) }\end{array}$ & $\begin{array}{l}\text { Співавтор твору. Як } \\
\text { правило, має профе- } \\
\text { сійну музичну освіту } \\
\text { і великий досвід. } \\
\text { Часто виступає ще й } \\
\text { аранжувальником та/ } \\
\text { або звукорежисером. } \\
\text { Фактично, є голов- } \\
\text { ною творчою ланкою } \\
\text { у сучасній масовій } \\
\text { музичній культурі, } \\
\text { але залишається для } \\
\text { слухачів маловідомим, } \\
\text { перебуває «в тіні» } \\
\text { виконавця. }\end{array}$ \\
\hline ПРОДЮСЕР & $\begin{array}{l}\text { Професійний мене- } \\
\text { джер. Як правило, } \\
\text { творча особистість, } \\
\text { пов’язана зі сферою } \\
\text { культури. Організа- } \\
\text { тор мистецьких акцій } \\
\text { і фестивалів, часто ці } \\
\text { події співфінансують } \\
\text { державні структури та } \\
\text { органи місцевої влади. }\end{array}$ & $\begin{array}{l}\text { Професійний мене- } \\
\text { джер, керує гру- } \\
\text { пою фахівців, осно- } \\
\text { вне завдання яких } \\
\text { - допомогти яскра- } \\
\text { вому солісту чи гурту } \\
\text { досягти комерційного } \\
\text { успіху. Як правило, } \\
\text { співпрацює з кількома } \\
\text { виконавцями. Для } \\
\text { слухачів залишається } \\
\text { маловідомим. }\end{array}$ \\
\hline $\begin{array}{l}\text { КОМУНІКА- } \\
\text { ТИВНИЙ } \\
\text { ПРОСТІР }\end{array}$ & $\begin{array}{l}\text { Як правило, представ- } \\
\text { ляє собою акустичний } \\
\text { концертний зал, іноді } \\
\text { телерадіотрансляції } \\
\text { відповідних музичних } \\
\text { творів, досі використо- } \\
\text { вуються CD- й DVD- } \\
\text { диски, є також чимало } \\
\text { професійних, люби- } \\
\text { тельських записів у } \\
\text { мережі Інтернет. }\end{array}$ & $\begin{array}{l}\text { Дуже багато «мікро- } \\
\text { фонних» майданчиків } \\
\text { - від маленьких сцен } \\
\text { до стадіонів, величезна } \\
\text { комерційна індустрія } \\
\text { шоу-бізнесу, «прямі» } \\
\text { трансляції на ТБ, } \\
\text { радіо та в Інтернеті, } \\
\text { безмежна кількість } \\
\text { аудіо- та відеофайлів } \\
\text { на інтернет-сайтах, } \\
\text { відеохостингах та у } \\
\text { соціальних мережах. }\end{array}$ \\
\hline
\end{tabular}


Продовження таблиці 1

\begin{tabular}{|c|c|c|}
\hline 1 & 2 & 3 \\
\hline СЛУХАЧ & $\begin{array}{l}\text { Як правило, інтелігент- } \\
\text { ний, освічений, вибаг- } \\
\text { ливий, віддає перевагу } \\
\text { концертним формам } \\
\text { спілкування з музи- } \\
\text { кою, аніж знайомству } \\
\text { з аудіо-, відеозаписами } \\
\text { творів у відеохостингах } \\
\text { чи соціальних мережах. }\end{array}$ & $\begin{array}{l}\text { 3разки масової куль- } \\
\text { тури, як правило, не } \\
\text { потребують від слухача } \\
\text { інтелігентності, осві- } \\
\text { ченості. Слухач звикає } \\
\text { до схожих творів у } \\
\text { масмедіа, нав'язливих } \\
\text { телепроектів, прямо- } \\
\text { ефірних шоу, процесу } \\
\text { обміну файлами у } \\
\text { соцмережах. Із легкі- } \\
\text { стю знаходить в Інтер- } \\
\text { неті улюблений відео- } \\
\text { кліп чи аудіозапис. }\end{array}$ \\
\hline
\end{tabular}

У таблицю «Роль основних ланок музичної комунікації» ми включили такі елементи комунікативної структури: композитор - твір - виконавець - саундпродюсер - продюсер - комунікативний простір - слухач. Тобто до 5 елементів базової, на наш погляд, структури музичної комунікації нами було додано ще дві додаткові ланки: продюсера, роль якого нині є дуже важливою як в академічному, так і в масовому музичному мистецтві, і саундпродюсера, якого в умовах XXI століття ми вважаємо однією з центральних фігур масової музичної культури.

Продюсер мистецтва академічного спрямування, як правило, є відомою особистістю, вшанованою державними відзнаками; часто продюсування концертів і фестивалів є лише одним із видів діяльності такого митця (зокрема, продюсер Олександр Пірієв є й керівником музичної редакції каналу «Культура» Українського радіо, продюсер Василь Вовкун генеральний директор-художній керівник Львівської Національної опери).

Не всі з досліджених нами продюсерів та саундпродюсерів масової культури мають відповідну фахову освіту. Так, продюсер і саундпродюсер Євген Філатов взагалі не має спеціалізованої музичної освіти (хоча батьки - випускники консерваторій), Продюсер Юрій Нікітін не став завершувати навчання, розпочате у Київському інституті культури і мистецтв, але обидва ці фахівці мають величезний досвід роботи у своїй царині. 
На наш погляд, у сучасній масовій культурі саундпродюсер $є$ співавтором музичного твору й однією з головних творчих ланок музично-комунікаційних процесів. Роль цього митця у створенні кінцевого результату часто є важливішою, ніж роль виконавця.

Серед тих українських саундпродюсерів, творчість яких була нами проаналізована, кожен, як правило, співпрацює одночасно 3 кількома комерційно успішними музикантами: М. Бусін - $з$ Maruv, Потапом і Н. Каменською, Pianoboy; С. Ермолаєв та А. Ігнатченко - 3 гуртами «Kazka», «Неангелы», А. Приходько, В. Козловським; Є. Філатов - з Jamala, гуртом «ONUKA», А. Данилком, Т. Кароль, Н. Могилевською, Гайтаною тощо.

Існує точка зору, що у сучасній масовій культурі чи не головну роль відіграє візуальний складник. Але проаналізовані нами дані демонструють, що музика для слухачів все одно залишається переважно аудіальним мистецтвом. Так, аудіоваріант пісні гурту «Kazka» «Плакала» (українською мовою), «викладений» у Інтернет-мережу, швидко набрав 50000000 прослуховувань - значно більше, аніж мешканців усієї України, тобто його, безсумнівно, прослуховували по кілька разів; також з'явилися, напевно, закордонні прихильники цього твору. Лише після такого значного успіху аудіоролику режисером Катею Царик був створений оригінальний відеокліп, який на даний момент має понад 312000000 переглядів.

Вагоме значення у збільшенні контактів творів академічного мистецтва зі слухачами нині відіграють телебачення, відеохостинги й соціальні мережі. Таким чином, підтверджується висновок О. Берегової про збільшення ролі візуального складника у сучасній академічній музичній культурі завдяки впливу засобів масової інформації [1, с. 32]. На значну роль вищезазначеного чинника вказують навіть партитури деяких сучасних творів академічної музики, зокрема «Небесний. Щедрик» композитора Івана Небесного, де серед списку виконавців указано «мультимедіа» (на екранах під час виконання демонструються відеокадри з подій на Майдані Незалежності взимку 2014 року).

Висновки. Феномен музичної комунікації є складною системою комунікативних ланок, елементи якої перебувають у структурній єдності і своєю взаємодією формують загальну цілісність. На основі досліджених наукових робіт та зібраних 
даних нами запропоновано таку базову структуру музичної комунікації у сучасному академічному та масовому мистецтві: композитор - твір - виконавець - медіаформа твору - комунікативний простір - слухач. Поняттям «твір» у цій структурі означено композиторський задум, нотний текст, партитуру; під поняттям «медіаформа твору» розуміється завершений (записаний і підготовлений до відтворення) трек, файл, кліп, ролик. Ця ланка може бути відсутньою, зокрема під час «живого», без використання фонограми, виконання академічних музичних творів. У поняття «комунікативний простір» ми включаємо: концертний зал, телерадіоефір, інтернет-простір.

У запропоновану схему структури музичної комунікації було включено ще кілька суб'єктів комунікації, а саме: видавця, редактора, критика (блогера), музикознавця, автора обробки, диригента (керівника виконавського колективу), педагога-консультанта, звукорежисера аудіозапису та концерту, відеорежисера та режисера трансляції, артдиректора, продюсера, саундпродюсера, саунддизайнера. Стрілками у пропонованій схемі вказано напрямок комунікативного процесу (однобічні стрілки) чи комунікаційної взаємодії елементів системи (двобічні стрілки).

Кількісний і якісний аналізи зібраних під час дослідження даних дозволив зробити висновки, які не розходяться 3 результатами інших наукових робіт. В академічному мистецтві було констатовано провідну роль майстра-митця (композитора і виконавця), котрий, як правило, впродовж багатьох років здобуває фахову освіту; у XXI столітті суттєво зросла роль музичного продюсера; не зазнала змін принципова некомерційність академічної музики; незважаючи на появу в інтернет-просторі чималої кількості записів творів академічного мистецтва, залишається значним інтерес слухачів до відвідування концертів і знайомства 3 музикою у «живому» виконанні.

У масовому музичному мистецтві відзначено такі особливості: переважальна анонімність авторів музики й текстів, центральна роль виконавця; можливість відсутності професійної музичної освіти у представників маскультури; нав'язування слухачам через ЗМІ штучно створеного виконавського образу; провідна роль музичного продюсера, особливо саундпродюсера, який іноді може виконувати також функції композитора, аранжувальника, звукорежисера. На основі дослі- 
джених наукових робіт та зібраних даних створено таблицю «Роль основних ланок музичної комунікації», під час заповнення якої було частково використано матеріали музикознавця О. Берегової [1].

Підсумовуючи загальні тенденції сучасних музично-комунікативних процесів, варто вказати на такі з них: зростання значення візуального складника в академічній музиці і дуже велика їі роль у масовій; значна роль яскравих особистостей (продюсерів, виконавців) як у академічній культурі, так і у масовій; до появи видатних досягнень у музичному мистецтві завжди причетні високопрофесійні митці, проте у маскультурі імена композиторів, поетів, аранжувальників, саундпродюсерів часто залишаються маловідомими слухачам.

У контексті цієї роботи лише частково вдалося дослідити різні аспекти складних i, як правило, різнорівневих процесів музичної комунікації. Тому вважаємо перспективи подальших досліджень у цьому напрямі багатообіцяючими.

\section{СПИСОК ЛІТЕРАТУРИ}

1. Берегова О.М. Академічне музичне мистецтво та сучасні інформаційно-комунікаційні технології: дискурс взаємодії. Аспекти історичного музикознавства. Харків, 2016. № 8. С. 24-35.

2. Злотник О.Й., Шульгіна В.Д. Комунікативні функції художнього спілкування в музичному мистецтві. Наукові записки Тернопільського національного педагогічного університету імені В. Гнатюка. Серія: Мистецтвознавство. Тернопіль, 2019. № 1 (вип. 40). С. 28-34.

3. Корсакова И.А. Музыкальная коммуникация: генезис и историко-культурные трансформации : автореф. дис. ... докт. культурологии : 24.00.01. Москва, 2014, 48 с.

4. Найдорф М.И. Об особенностях музыкальной культуры массового media-пространства. Вопросы культурологии. Москва, 2007. Вып. 6. С. 70-72.

5. Орлова И. Предпосылки становления грамзаписи. Рождение звукового образа: (Художественные проблемы в экранных искусствах и на радио) : сб. статей / сост. Е. М. Авербах. Москва, 1985. С. 22-34.

6. Сергеева И.В. Особенности коммуникационных процессов массовой музыкальной культуры : автореф. дис. ... канд. социол. наук : 22.00.06. Саратов, 2004, 16 с.

\section{REFERENCES}

1. Berehova O. M. (2016) Akademichne muzychne mystetstvo ta suchasni informatsiino-komunikatsiini tekhnolohii: dyskurs vzaiemodii [Academic music art and modern information and communication tech 
nologies: discourse of interaction]. Aspects of Historical Musicology, no. 8, pp. $24-35$.

2. Zlotnyk, O. Y., Shulhina, V. D. (2019) Komunikatyvni funktsii khudozhnoho spilkuvannia $\mathrm{v}$ muzychnomu mystetstvi [Communicative function of artistic conversation in the musical art]. Scientific Issues of Ternopil Volodymyr Hnatiuk National Pedagogical University are. Series: Art Studies, no. 1, pp. 28-34.

3. Korsakova I. A. (2014) Muzykalnaia kommunikatsiia: genezis $i$ istoriko-kulturnye transformatsii [Musical communication: genesis and historical and cultural transformations] (doctoral dissertation), Moscow: Moscow State Institute of Culture.

4. Naidorf M. I. (2007) Ob osobennostiakh muzykalnoi kultury massovogo media-prostranstva [On the features of the musical culture of the massive media space] Issues of Cultural Studies, is. 6, pp. 70-72.

5. Orlova I. (1985) Predposylki stanovleniia gramzapisi [Prerequisites for the formation of a gramophone recording]. Rozhdenie zvukovogo obraza: (Khudozhestvennye problemy $v$ ekrannykh iskusstvakh $i$ na radio) [Birth of a sound image: (Art problems in screen arts and radio)]. Moscow: Iskusstvo, pp. 22-34.

6. Sergeeva I. V. (2004) Osobennosti kommunikatsionnykh protsessov massovoi muzykalnoi kultury [Features of communication processes of massive musical culture] (PhD Thesis), Saratov: Saratov State Technical University. 